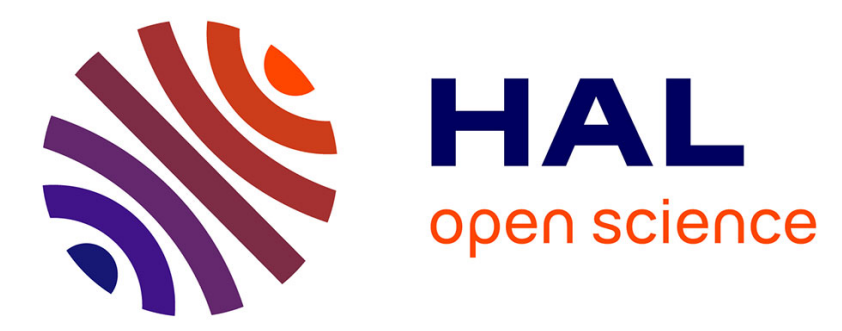

\title{
Aerosol lofting from sea breeze during the Indian Ocean experiment
}

S. Verma, O. Boucher, C. Venkataraman, M. Reddy, D. Muller, P. Chazette, B. Crouzille

\section{- To cite this version:}

S. Verma, O. Boucher, C. Venkataraman, M. Reddy, D. Muller, et al.. Aerosol lofting from sea breeze during the Indian Ocean experiment. Journal of Geophysical Research: Atmospheres, 2006, 111, pp.D07208. 10.1029/2005JD005953 . hal-02902865

\section{HAL Id: hal-02902865 \\ https://hal.science/hal-02902865}

Submitted on 15 Apr 2021

HAL is a multi-disciplinary open access archive for the deposit and dissemination of scientific research documents, whether they are published or not. The documents may come from teaching and research institutions in France or abroad, or from public or private research centers.
L'archive ouverte pluridisciplinaire HAL, est destinée au dépôt et à la diffusion de documents scientifiques de niveau recherche, publiés ou non, émanant des établissements d'enseignement et de recherche français ou étrangers, des laboratoires publics ou privés. 


\title{
Aerosol lofting from sea breeze during the Indian Ocean Experiment
}

\author{
S. Verma, ${ }^{1}$ O. Boucher, ${ }^{2,3}$ C. Venkataraman, ${ }^{1}$ M. S. Reddy, ${ }^{2,4}$ D. Müller, ${ }^{5}$ P. Chazette, ${ }^{6}$ \\ and B. Crouzille ${ }^{2}$ \\ Received 7 March 2005; revised 22 September 2005; accepted 18 January 2006; published 14 April 2006.
}

[1] This work was carried out to understand the mechanisms leading to lofting and largescale advection of aerosols over the Indian Ocean region due to interaction of the sea breeze with the northeast monsoon winds along the west coast of India. European Centre for Medium-Range Weather Forecasts (ECMWF) wind fields for the months of February and March 1999 were analyzed at various times of day. Intense sea breeze activity was observed at 1200 UT (1730 local time) along the west coast of India with average intensity larger in March than in February. The sea breeze was seen to extend inland deeper in March than in February. Lofting of air observed as high as $800 \mathrm{hPa}$ (approximately $2 \mathrm{~km}$ above sea level) could lead to entrainment of aerosols into the free troposphere and long-range transport. Upward motion of air was observed everywhere along the west coast of India (from $8^{\circ}$ to $20^{\circ} \mathrm{N}$ ), on average higher in March than in February, because of convergence between the sea breeze and the synoptic-scale flow. A region of intense lofting of air and well-defined convergence was observed along the coast of the Karnataka region $\left(12^{\circ}-16^{\circ} \mathrm{N}\right)$. A simulation with a general circulation model nudged with ECMWF data indicated that the intrusion of marine air masses with low concentrations of organic matter is seen as deep as $64 \mathrm{~km}$ inland in the evening (1500 UT). Intrusion of the sea-salt plume is seen to a maximum distance of around $200 \mathrm{~km}$ from 1500 until 2300 UT. A well-developed lofted layer of aerosols as high as $3 \mathrm{~km}$ was also simulated during sea breeze activity along the west coast of India. The general circulation model simulation shows a clear diurnal evolution of the vertical profile of the aerosol extinction coefficient at Goa but fails to reproduce several features of the lidar observations, for example, the marked diurnal variability of the upper layers between 1 and $3 \mathrm{~km}$. However, the model simulates a diurnal cycle at the surface $(0-0.7 \mathrm{~km})$ that is not apparent in lidar measurements. The model simulates long-range transport and captures the lofted plume downwind of the west coast of India. However, there was a 1-2 day delay in the model transport of lofted aerosols at higher layers to Hulule, $700 \mathrm{~km}$ downwind of India, when compared to lidar observations.

Citation: Verma, S., O. Boucher, C. Venkataraman, M. S. Reddy, D. Müller, P. Chazette, and B. Crouzille (2006), Aerosol lofting from sea breeze during the Indian Ocean Experiment, J. Geophys. Res., 111, D07208, doi:10.1029/2005JD005953.

\section{Introduction}

[2] The intensive field phase of the Indian Ocean Experiment (INDOEX-IFP), was conducted during the northeast winter monsoon season, January-March 1999, to assess the

\footnotetext{
${ }^{1}$ Department of Chemical Engineering, Indian Institute of Technology Bombay, Bombay, India.

${ }^{2}$ Laboratoire d'Optique Atmosphérique, CNRS-Université des Sciences et Technologies de Lille, Villeneuve d'Ascq, France.

${ }^{3}$ Now at Hadley Centre, Met Office, Exeter, UK.

${ }^{4}$ Now at University Corporation for Atmospheric Research, NOAA Geophysical Fluid Dynamics Laboratory, Princeton, New Jersey, USA.

${ }^{5}$ Institute for Tropospheric Research, Leipzig, Germany.

${ }^{6}$ Laboratoire des Sciences du Climat et de 1'Environnement, CEACNRS, Gif-sur-Yvette, France.

Copyright 2006 by the American Geophysical Union. 0148-0227/06/2005JD005953
}

role of aerosols on climate [Ramanathan et al., 2001]. Extensive observational studies from multiple platforms established widespread aerosol loading over oceanic regions [Lelieveld et al., 2001; Krishnamoorthy et al., 2001; Ball et al., 2003]. A striking feature was the presence, especially in March 1999, of multiple aerosol layers located above the boundary layer between 1 to $4 \mathrm{~km}$ in height. These elevated layers were observed at the continental stations of Goa and Dharwar on the west coast [Leon et al., 2001; Chazette, 2003], over the ocean [Reiner et al., 2001], and over in the Maldives, about a thousand kilometers downwind of Indian subcontinent [Müller et al., 2001a, 2001b; Franke et al., 2003]. These layers contained anthropogenic aerosols including sulfate and other inorganic species, black carbon (BC), organic carbon (OC), and windblown mineral dust [Gabriel et al., 2002; Mayol-Bracero et al., 2002; Leon et al., 2001; Chazette, 2003]. On some occasions, they 


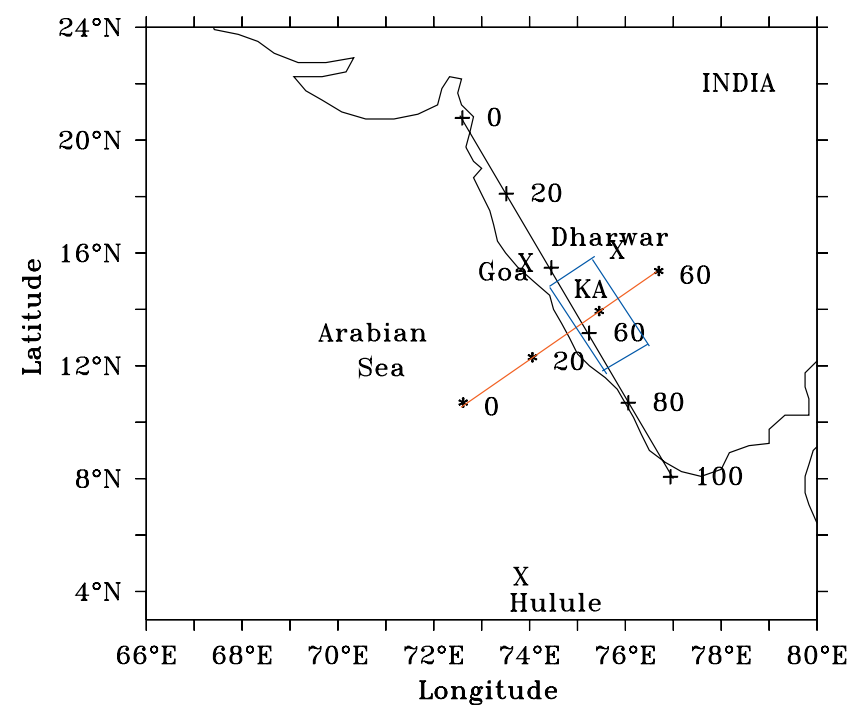

Figure 1. Region of focus and location of the coastal and transverse planes. The locations of Goa, Dharwar, and Hulule are indicated by crosses. Karnataka region is indicated by the letters "KA" bounded within a box. Distance scale along the planes is as follows: coastal plane, 20 points equals $275 \mathrm{~km}$; transverse plane, 20 points equals $160 \mathrm{~km}$. These points are referred to with the variable $x$ in the text.

exhibited high extinction-to-backscatter ratios implying the presence of absorbing aerosols, potentially arising from biomass burning regions over India [Franke et al., 2003]. According to Raman et al. [2002], the strength and coherence of the elevated plume was influenced by the diurnal variation of the structure of the upwind continental boundary layer.

[3] Land and sea breeze are well known meteorological phenomena [Miller et al., 2003]. Land and sea breeze systems are caused by the temperature differences over two surfaces. Sea breeze occurs at day when the landmasses are hotter than the ocean, while land breeze occurs at night when landmasses have cooled faster than the ocean. A detailed analysis of structure and impacts of sea breeze has recently been done by Miller et al. [2003]. It has been suggested that the aerosol lofting and large-scale advection during INDOEX was mediated by the interaction of the land and sea breeze cycle on the west coast of India with the regional-scale northeast monsoon flow, whereby aerosols can be lofted above the boundary layer and entrained into the regional-scale flow [Leon et al., 2001]. The similar magnitude of aerosol optical depth (AOD) observed at Goa (coastal station, $\left.73.13^{\circ} \mathrm{E}, 15.75^{\circ} \mathrm{N}\right)$ and Dharwar $(150 \mathrm{~km}$ inland; $\left.75.63^{\circ} \mathrm{E}, 15.7^{\circ} \mathrm{N}\right)$ suggested that aerosol loads are part of a large-scale feature. Also, the lack of temporal correlation in the near-surface concentrations of aerosols and the column AOD implied that the respective evolutions of aerosols in the boundary layer and the elevated layer were affected by distinct mechanisms, potentially emissions in the boundary layer and large-scale transport in the elevated layer [Leon et al., 2001]. The clear diurnal variability in the vertical extent and AOD of the elevated layer [Chazette, 2003] also suggested an effect of the sea breeze.
[4] The first aerosol transport modeling studies of the INDOEX IFP have examined aerosol distributions, the contributions from different species to the AOD [Collins et al., 2001; Rasch et al., 2001], and a qualitative estimate of regional contributions to the aerosol load. Recently, Minvielle et al. [2004a, 2004b] modeled the transport of aerosols during INDOEX using a mesoscale model and explained the spatial and temporal distributions of aerosols (black carbon, sulfur dioxide, and soil dust) and their contribution to aerosol optical depth. Using a fine source classification and increased spatial resolution over the INDOEX domain in the general circulation model of the Laboratoire de Météorologie Dynamique (LMD-ZT), Reddy et al. [2004] demonstrated that sulfate and carbonaceous aerosols are main contributors to the AOD. They also showed that, although south Asian emissions contribute significantly to sulfate and carbonaceous aerosol loads over the Indian Ocean, large-scale transport from source regions outside south Asia was also important. This model study was extensively evaluated against INDOEX-IFP measurements and provides a useful tool to examine the mechanisms affecting large-scale advection of aerosols. These mechanisms have been previously examined using a mesoscale model for aerosol transport [Leon et al., 2001]. However the model was run over a small domain $\left(73^{\circ} \mathrm{E}\right.$ to $76^{\circ} \mathrm{E}, 14^{\circ} \mathrm{N}$ to $16^{\circ} \mathrm{N}$ ) and for a period of 48 hours only. Both Leon et al. [2001] and Raman et al. [2002] show a schematic representation of the interactions between the sea breeze and the large-scale flow but do not present explicit model results showing the resulting aerosol distributions. The zoom facility of the LMD-ZT model gives us an opportunity to re-examine these issues using simulations on a larger domain and for a longer time period. Therefore the specific objectives of the present study are to (1) simulate the aerosol transport during INDOEX-IFP in the LMD-ZT at an increased horizontal and vertical resolution, (2) evaluate the effects of sea breeze including the extent of inland incursion of winds and increase in vertical mass flux from convergence with the NE monsoon flow, (3) analyze the link between aerosol lofting from the sea breeze circulation and large-scale advection of elevated aerosol layers, as established in the observational studies, and (4) examine the model simulated diurnal variations of the elevated aerosol layers and their dependence on the sea breeze circulation.

\section{Method of Study}

\subsection{ECMWF and Observational Data}

[5] The data set consists of horizontal (zonal and meridional) and vertical wind fields from meteorological analysis of the European Centre for Medium-Range Weather Forecasts (ECMWF) for the months of February and March 1999. The data are provided on a regular latitude-longitude grid of $0.5^{\circ} \times 0.5^{\circ}$ over standard pressure levels $(1000,925$, $850,700,500,400,300,250,200,150,100,70,50,30$, and $10 \mathrm{hPa}$ ). The data set covers a window from $35^{\circ} \mathrm{S}$ to $35^{\circ} \mathrm{N}$ and $30^{\circ} \mathrm{E}$ to $110^{\circ} \mathrm{E}$, with a temporal resolution of 6 hours (at 0000, 0600, 1200, and 1800 UT).

[6] The region of focus in the present study extends from $66^{\circ} \mathrm{E}$ to $80^{\circ} \mathrm{E}$ and $3^{\circ} \mathrm{N}$ to $24^{\circ} \mathrm{N}$ as shown in Figure 1 . The analysis of the wind fields is carried out along different 
planes (Figure 1). A coastal plane is located inland of the west coast and parallel to the coastline of India. On an arbitrary scale of 100 , the distance between nearest tick marks, spanning 20 divisions, is about $275 \mathrm{~km}$ for the coastal plane which runs from locations of Daman and Diu (0th point) to Thiruvananthapuram (100th point). The coastal plane is used to evaluate the vertical extent of air mass and aerosol lofting due to the convergence of the sea breeze with the regional-scale NE monsoon flow. A transverse plane is defined, which crosses the coastal plane, to analyze the vertical and horizontal extent of sea breeze circulation and lofting of air. On an arbitrary scale of 60 , the distance between nearest tick marks, spanning 20 divisions, is about $160 \mathrm{~km}$ for the transverse plane. These planes have been chosen within the zone of maximum convergence (along the Karnataka region as marked in Figure 1) between sea breeze and northeast monsoon winds.

[7] The coastal stations of Goa and Dharwar are chosen to study the effects of sea breeze circulation. The station of Hulule located about $700 \mathrm{~km}$ off the coast is used to analyze the synoptic-scale advection of aerosols over the ocean.

\subsection{Short Description of the LMD-ZT GCM}

[8] The study of lofting and synoptic-scale advection of aerosols is carried out with the help of the LMD-ZT general circulation model (GCM), version 3.3. A description of the atmospheric model is given by $L i$ [1999] and a specific description of aerosol treatment is given by Boucher et al. [2002] and Reddy et al. [2004, 2005]. Only a short description is repeated here.

[9] In LMD-ZT atmospheric transport is computed with a finite volume transport scheme for large-scale advection [van Leer, 1977; Hourdin and Armangaud, 1997], a scheme for turbulent mixing in the boundary layer, and a mass flux scheme for convection [Tiedtke, 1989]. The vertical transport of trace species is accounted for in updrafts, downdrafts, with entrainment and detrainment from and to the environment, and in the environment itself. The sulfur cycle has been incorporated and processes of convective transport, wet scavenging, and aqueous-phase chemistry have been parameterized as consistently as possible with the model physical parameterizations [Boucher et al., 2002]. Sulfate formation, transport, and radiative forcing were estimated by Boucher et al. [2002]. The atmospheric cycles of carbonaceous aerosols, sea salt, and dust are described by Reddy and Boucher [2004] and Reddy et al. [2004, 2005]. Emissions of $\mathrm{SO}_{2}, \mathrm{BC}$ (black carbon), and organic carbon (OC) from fossil fuel and biomass sources over Asia are from Streets et al. [2003], but emissions over India are from the high-resolution $\left(0.25^{\circ} \times 0.25^{\circ}\right)$ emission inventories of Reddy and Venkataraman [2002a, 2002b]. Aerosol optical properties (mass extinction coefficient, $\alpha_{e}$; single-scattering albedo, $\omega$; and asymmetry factor, $g$ ) for all aerosol species are computed using Mie theory as described by Reddy et al. [2004]. The aerosol extinction coefficient is computed from all aerosol species and associated water.

\section{Analysis of Sea Breeze Using ECMWF- Analyzed Wind Fields}

[10] The ECMWF data were analyzed at various times of day $(0000,0600,1200$, and 1800 UT) to identify the periods of sea breeze activity. In February 1999 the sea breeze is observed at $1200 \mathrm{UT}$, corresponding to a local time of $1730 \mathrm{LT}$, but is absent at the other times of the day. In March 1999, sea breeze lasts longer from 0600 to 1800 UT, with the largest intensity at 1200 UT. We therefore analyze the sea breeze related effects at 1200 UT for both months. The monthly mean surface horizontal wind fields for February and March 1999 at 0000 and 1200 UT are shown in Figure 2. Convergence between the sea breeze and the synoptic-scale flow is observed everywhere along the west coast of India (from 8 to $20^{\circ} \mathrm{N}$ ) at $1200 \mathrm{UT}$. The average horizontal surface wind speed at 1200 UT through the coastal plane (in the direction of the transverse plane) is $1.4 \mathrm{~m} \mathrm{~s}^{-1}$ in February. Significantly large values of $3.4 \mathrm{~m}$ $\mathrm{s}^{-1}$ were found for March. The larger intensity of the sea breeze in March is expected because of the higher temperature of Indian subcontinent in March [Miller et al., 2003] that causes a larger contrast in temperature between ocean and land. The vertical wind velocity at $1000 \mathrm{hPa}$ is also shown in Figure 2. Large negative values are observed at 1200 UT along the west coast, indicating convergence of air and subsequent upward motion. In contrast an intense downdraft of air mass is seen at 0000 UT (Figure 2a) along the west coast of India inferring to strong downward motion observed at $0000 \mathrm{UT}$ along the same coastal region. However this feature is only observed in February. In March, (Figure 2b) a weak downdraft of air mass or presence of almost neutral conditions exist along the west coast at 0000 UT. Since, the downdraft of air mass is related to land breeze activity prevalent along the west coast, presence of intense land breeze activity is inferred along the west coast for February at 0000 UT as compared to that for March. The longer temporal extension of the sea breeze in March, from 0600 to 1800 UT, is also evidenced in the maps of vertical velocities (not shown). The presence of weak land breeze activity at 0000 UT and that the longer temporal extension of sea breeze in March as compared to that in February is again due to higher temperature of Indian subcontinent in March as compared to February. The average velocity of upward motion at the surface along the coastal plane at $1200 \mathrm{UT}$ is $0.24 \mathrm{~Pa} \mathrm{~s}^{-1}$ during March as compared to $0.12 \mathrm{~Pa} \mathrm{~s}^{-1}$ for February. Larger updrafts as observed in March from an analysis of ECMWF wind fields will have a greater potential for lofting of aerosols.

[11] Figure 3 represents the vertical profile of the vertical mass flux along the coastal plane. It shows upward rising of air as high as $800 \mathrm{hPa}$ (approximately $2 \mathrm{~km}$ above sea level (asl)) all along the coastal plane with the largest intensity within points 40 to 70 (corresponding to the coordinates of $74.30^{\circ} \mathrm{E}, 15.80^{\circ} \mathrm{N}$ and $75.65^{\circ} \mathrm{E}, 11.90^{\circ} \mathrm{N}$ ) along the west coast of India. The vertical profile of the vertical mass flux is also plotted along the transverse plane which has been chosen to lie within the region of intense upward motion defined above (Figure 4). We observe intense upward motion within points 35 to 45 (corresponding to the coordinates of $74.92^{\circ} \mathrm{E}, 13.30^{\circ} \mathrm{N}$ and $75.61^{\circ} \mathrm{E}, 14.12^{\circ} \mathrm{N}$ ). It is interesting to note that the strongest upward motion does not occur at the surface but at higher altitudes. In March, the upward motion extends well above $800 \mathrm{hPa}$ and as high as $600 \mathrm{hPa}$. The region of upward motion at 1200 UT is mostly located over land and is accompanied by a weaker downward motion off the coast. Figure 5 

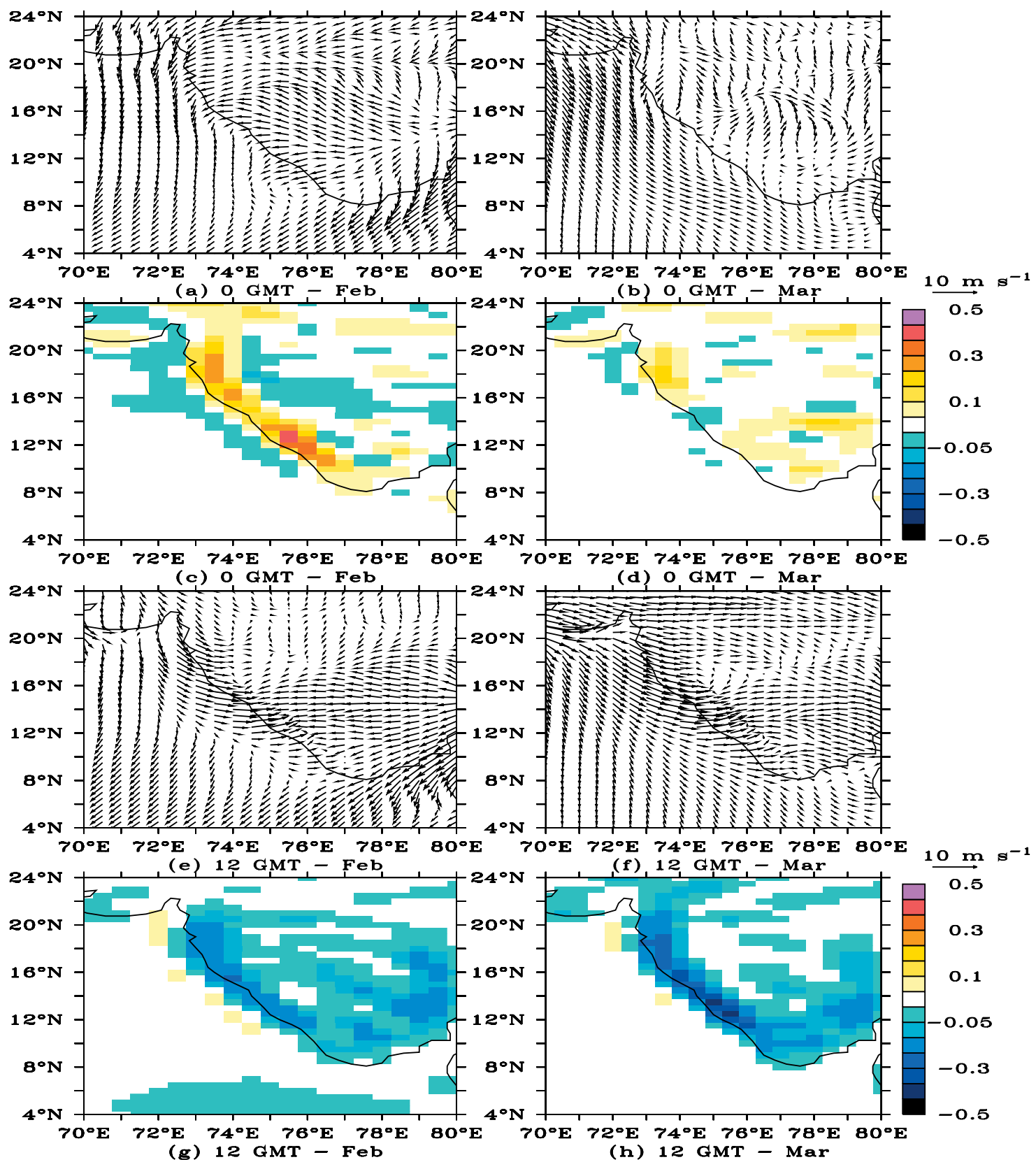

Figure 2. Vector of horizontal wind fields $\left(\mathrm{m} \mathrm{s}^{-1}\right)$ at $1000 \mathrm{hPa}$ and $0000 \mathrm{UT}$ for (a) February and (b) March 1999 and (c and d) corresponding vertical wind velocity $\left(\mathrm{Pa} \mathrm{s}^{-1}\right)$. Vector of horizontal wind fields $\left(\mathrm{m} \mathrm{s}^{-1}\right.$ ) at $1000 \mathrm{hPa}$ and $1200 \mathrm{UT}$ for (e) February and (f) March 1999 and (g and h) corresponding vertical wind velocity $\left(\mathrm{Pa} \mathrm{s}^{-1}\right)$. Scale for wind velocity is indicated to the right of vector plots by arrows representing $10 \mathrm{~m} \mathrm{~s}^{-1}$.

further shows the monthly mean wind vectors projected onto the transverse plane at 0000 and 1200 UT for February and March showing the horizontal and vertical extent of the sea breeze circulation. The wind vectors show the convergence between the onshore sea breeze winds at 1200 UT and the northeast monsoon winds leading to updraft of air mass: between regions of $x=35$ and 45 . The sea breeze winds retreats back with the northeast monsoon winds at a pressure level of $850 \mathrm{hPa}$, corresponding to a vertical extent of the sea breeze circulation of approximately $1.5 \mathrm{~km}$. Sea breeze is seen to extend to about $100 \mathrm{~km}$ inland in February, but goes deeper to about $150 \mathrm{~km}$ inland in March. The wind vectors at 0000 UT show the intense down trend and offshore flow of air in February (indicating the presence of strong land breeze activity) while a weak down trend (almost a neutral condition) and offshore flow of air in March (indicating the presence of weak land breeze activity as compared to February). In conclusion an area of welldefined convergence was found to occur around 1200 UT along the coastal plane with a maximum located at the coast of the Karnataka region. This location of well-defined convergence zone also justifies the optimum location of 


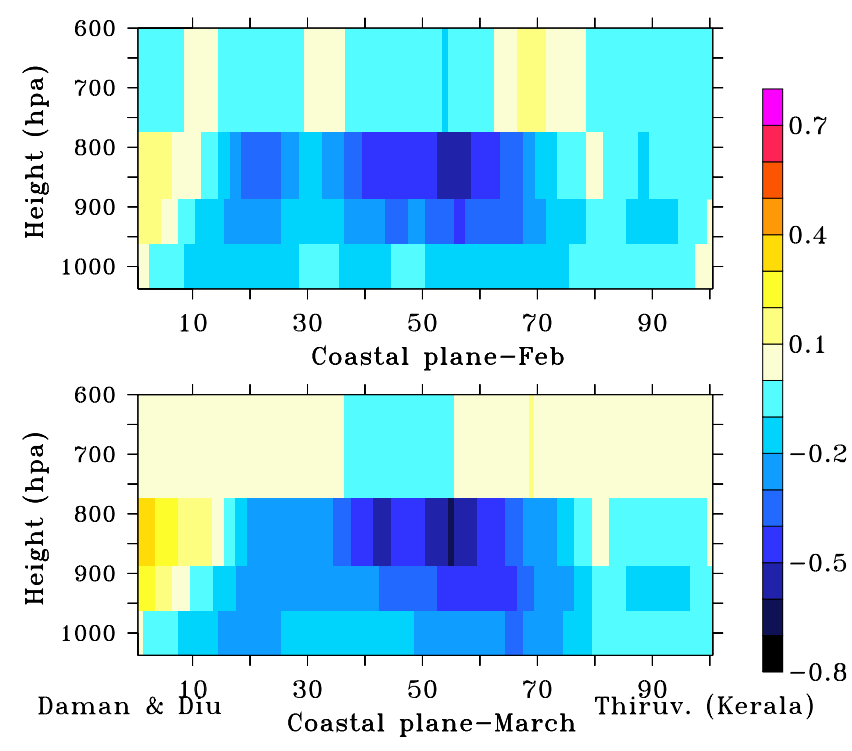

Figure 3. Monthly mean vertical mass flux of air $\left(\mathrm{Pa} \mathrm{s}^{-1}\right)$ along the coastal plane at 1200 UT for (a) February and (b) March 1999.

the coastal and transverse planes chosen for this study. Recently, Simpson and Raman [2005] proposed a hypothesis involving the sea breeze and land breeze circulations to describe the development and propagation of a pollution gradient in the marine boundary layer over the Arabian Sea during INDOEX 1999. This study discussed the formation of a well-developed sea breeze at 1700 LT and land breeze at $0500 \mathrm{LT}$ at Mangalore (Karnataka State, India). An interesting feature in the study was the simulation of a region of convergence along the west coast of India during the time of the sea breeze activity at 1700 LT. These results support our analysis based on ECMWF wind fields about the presence of sea breeze activity at 1200 UT (1730 LT) and updraft of air mass along the west coast of India.

[12] The mean altitude of the daily planetary boundary layer at the coastal location of Goa $\left(73.08^{\circ} \mathrm{E}, 15.45^{\circ} \mathrm{N}\right)$ was observed to be close to $0.7 \mathrm{~km}$ throughout the complete measurement period [Leon et al., 2001]. Lofting of air above $800 \mathrm{hPa}(2 \mathrm{~km}$ asl $)$ along the coast into and above the mixing zone of sea breeze circulation $(1 \mathrm{~km}$ asl $)$ into the free troposphere due to convergence between sea breeze and the prevailing NE monsoon winds could lead to entrainment of aerosols into the free troposphere causing their largescale advection. Several observational studies over the Indian Ocean showed the presence of lofted aerosol layers during March 1999 (Table 1). The main reason for the observed layering over an island $\left(4.1^{\circ} \mathrm{N}, 73.3^{\circ} \mathrm{E}\right)$ was believed to be the lofting of the continental air above the marine boundary layer when the pollution plumes are advected across the coastline [Ansmann et al., 2000; Franke et al., 2003].

\section{Experimental Setup of the LMD-ZT GCM}

[13] The model resolution is increased from $96 \times 72$ to $192 \times 145$ points in longitude and latitude, respectively. The number of vertical layers has been increased to 50 , with eleven layers below $850 \mathrm{hPa}$ and eight layers between 850 and $500 \mathrm{hPa}$. A zoom is applied over the Indian region; it is centered at $75^{\circ} \mathrm{E}$ and $15^{\circ} \mathrm{N}$ and extends from $50^{\circ} \mathrm{E}$ to $100^{\circ} \mathrm{E}$ in longitude and from $5^{\circ} \mathrm{S}$ to $35^{\circ} \mathrm{N}$ in latitude. Zoom factors of 4 and 3 are applied in longitude and latitude, respectively, resulting in a resolution of about $0.47^{\circ} \times 0.47^{\circ}$ over the zoomed region. Outside the zoomed region, the model has a resolution of $1.87^{\circ} \times 1.24^{\circ}$. ECMWF global winds (at a resolution of $1.25^{\circ} \times 1.25^{\circ}$ ) are regridded to the model grid. ECMWF INDOEX winds (at a resolution of $0.5^{\circ} \times 0.5^{\circ}$, as described above), are also regridded to the model grid and pasted into the global wind data set. The ECMWF model uses a hybrid vertical coordinate which follows the contours of the Earth surface in the lower and middle troposphere. Here the winds are interpolated at $1000 \mathrm{hPa}$ at places where the surface pressure is less than $1000 \mathrm{hPa}$. These data are then used to nudge the model, with a relaxation time of 0.05 days. This ensures that the patterns of sea breeze, which are evident in the ECMWF data, are well captured by the model. Figure 6 shows the direction of the surface wind at Goa from ECMWF analysis and from the model after nudging. The wind direction is calculated as per meteorological convention whereby a wind from the north has a direction of $0^{\circ}$, from the east a direction of $90^{\circ}$, from the south a direction of $180^{\circ}$, and from the west a direction of $270^{\circ}$. The nudged winds from the model shows a very good agreement with the original surface winds of ECMWF. This indicates that the model with nudging captures well the patterns of sea and land breeze from analyzed ECMWF winds. On days which show a large variation the wind direction varies approximately in phase with the observed wind direction reported by Chazette [2003] (note that their Figure 16 is in local time) for the period from 1 March to 15 March. Interestingly, ECMWF wind data also indicate a number of days where the wind direction does not vary much around 300-350 degrees (versus 270-330 degrees in the study by Chazette [2003]). To understand the effect of sea breeze cycle on aerosols, we simulate the period from 15 February to 26 March. Considering a 10 day spin up, we
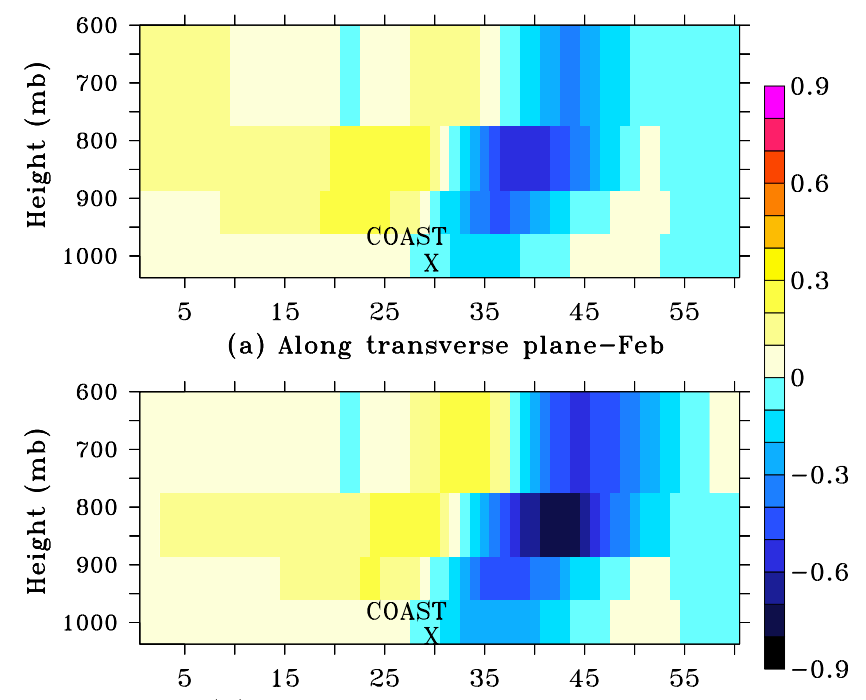

(b) Along transverse plane-March

Figure 4. Monthly mean vertical mass flux of air $\left(\mathrm{Pa} \mathrm{s}^{-1}\right)$ along the transverse plane at 1200 UT for (top) February and (bottom) March 1999. 


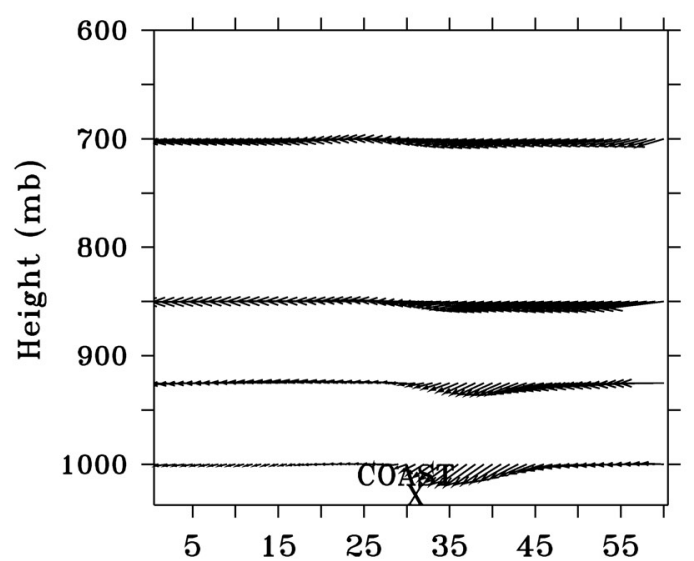

(a) Transverse plane-Feb (0 GMT)

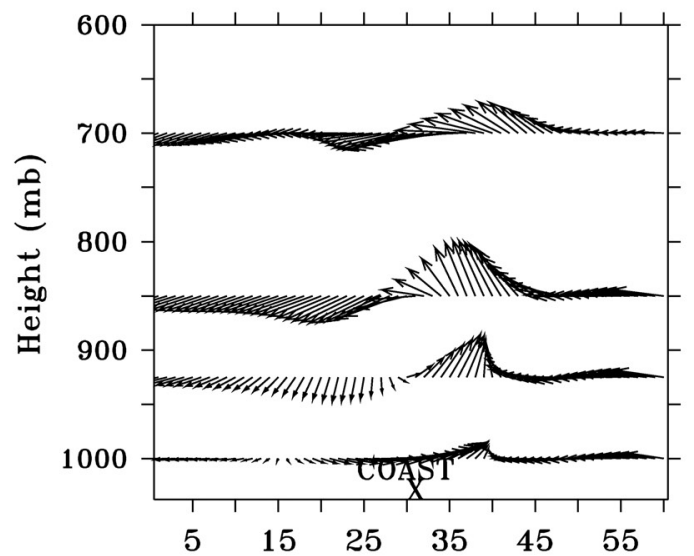

(c) Transverse plane-Feb (12 GMT)

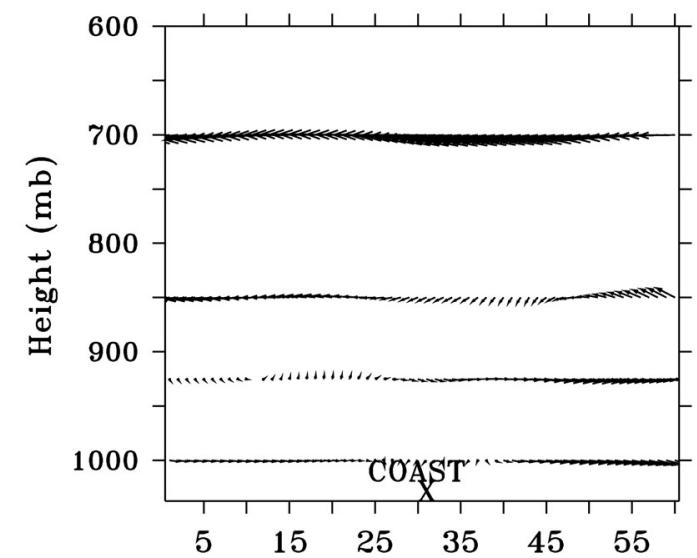

(b) Transverse plane-March (0 GMT)

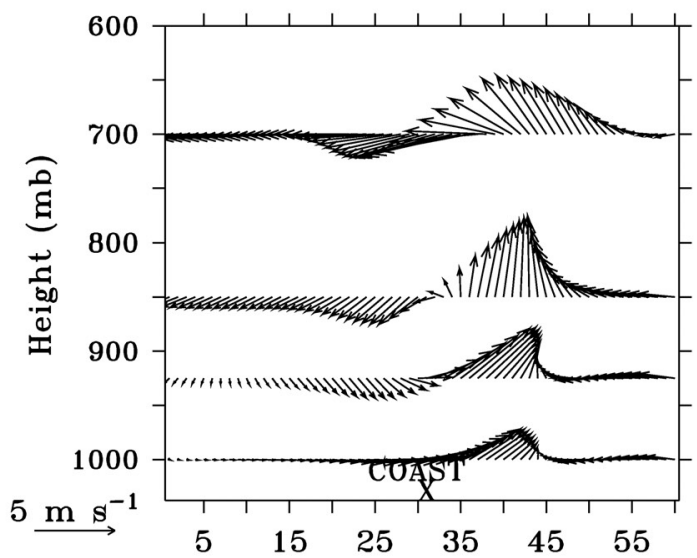

(d) Transverse plane-March (12 GMT)

Figure 5. Vectors of the monthly mean horizontal wind in the transverse plane $\left(\mathrm{m} \mathrm{s}^{-1}\right)$ and vertical wind velocity $\left(\times 10\right.$ in Pa s$\left.^{-1}\right)$ at (a and b) 0000 UT and (c and d) 1200 UT for February and March 1999, respectively, representing the horizontal and vertical extent of sea breeze circulation. The scale for the horizontal wind velocity is indicated between Figures $5 \mathrm{c}$ and $5 \mathrm{~d}$ by an arrow representing $5 \mathrm{~m} \mathrm{~s}^{-1}$.

only examine model outputs from 25 February to 26 March, with a time resolution of 2 hours for concentrations of sulfate, black carbon $(\mathrm{BC})$, organic matter $(\mathrm{OM})$, and sea salt, and 30 minutes for the vertical profile of the extinction coefficient at Goa and Hulule.

\section{Sea Breeze Effects on Lofting and Vertical Distribution of Aerosols}

[14] This study is carried out with the help of a highresolution simulation as described in section 4 . We provide animations showing two- and three-dimensional representations of aerosol plumes as additional material. We concentrate on two species with similar lifetime but different origins, namely $\mathrm{OM}$ and submicronic sea salt. $\mathrm{BC}$ would show similar patterns as OM, while sulfate has both continental and maritime sources and would be more difficult to interpret.

[15] Four different animations can be downloaded which show the evolution of $\mathrm{OM}$ and sea salt concentrations along the west coast of India (Animation 1 and 2) and in the transverse plane (Animations 3 and 4). Visualization of the

Table 1. Summary of Observational Studies Showing the Temporal and Spatial Extent of Elevated Aerosol Plumes in 1999

\begin{tabular}{|c|c|c|c|c|c|c|}
\hline \multirow{2}{*}{$\begin{array}{c}\text { Period of } \\
\text { Pollution Episodes }\end{array}$} & \multirow[b]{2}{*}{ Platform } & \multicolumn{3}{|c|}{ Region of Study } & \multirow{2}{*}{$\begin{array}{c}\text { Depth of } \\
\text { Elevated Plume, } \mathrm{m}\end{array}$} & \multirow[b]{2}{*}{ Reference } \\
\hline & & Station & Latitude & Longitude & & \\
\hline $18 \mathrm{Feb}$. to $25 \mathrm{March}$ & lidar & Hulule & $4.1^{\circ} \mathrm{N}$ & $73.3^{\circ} \mathrm{E}$ & $1000-3200$ & $\begin{array}{l}\text { Ansmann et al. }[2000], \\
\text { Müller et al. }[2001 \mathrm{a}], \\
\text { Pelon et al. }[2002], \\
\text { Franke et al. }[2003], \\
\text { Wagner et al. }[2001]\end{array}$ \\
\hline Feb. to March & $\begin{array}{l}\mathrm{C}-130 \\
\text { aircraft }\end{array}$ & - & $8^{\circ}-15^{\circ} \mathrm{N}$ & $70^{\circ}-85^{\circ} \mathrm{E}$ & $1000-3200$ & $\begin{array}{l}\text { Reiner et al. [2001], } \\
\text { Mayol-Bracero et al. [2002], } \\
\text { Gabriel et al. }[2002]\end{array}$ \\
\hline
\end{tabular}




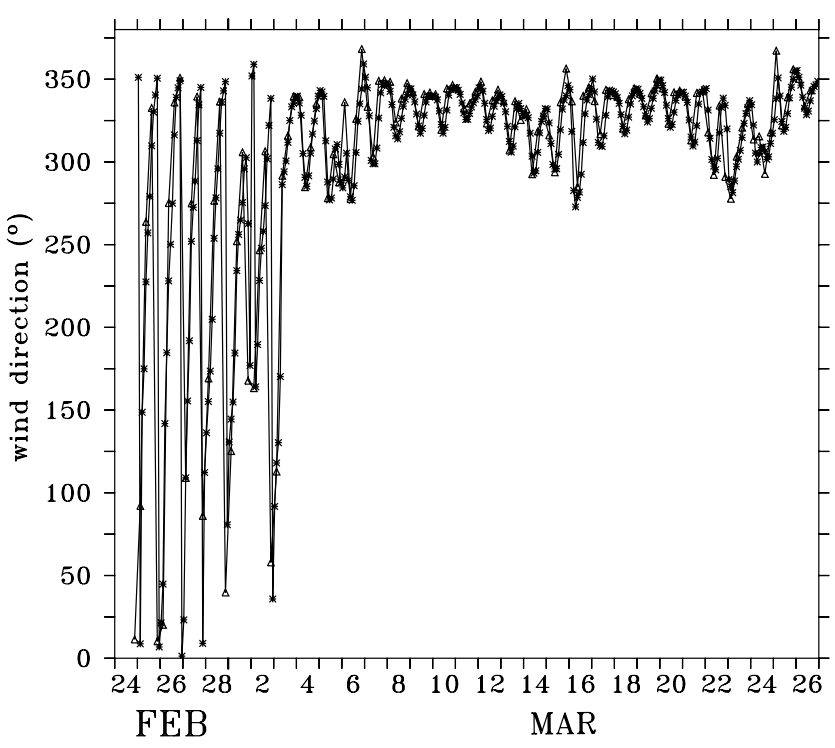

Figure 6. Temporal evolution of the wind direction from the GCM simulations (stars) and the original ECMWF analysis (triangles) for the period from 25 February to 26 March 1999. The $x$ axis corresponds to days in universal time. The wind direction is given in accordance with meteorological convention (i.e., $0^{\circ}$ for wind coming from the north, $90^{\circ}$ for wind coming from the east, and so forth) except for two data points where the ECMWF wind direction is reported with values slightly larger than $360^{\circ}$.

3D animations, time step by time step, reveals the effect of land and sea breeze on the aerosol plumes. On almost every day the isosurface of OM concentrations oscillates at the surface along the west coast of India. The isosurface of OM concentrations can also be seen to move up along the west coast at time around 2100 UT and later although not every day (it is particularly visible on 20,23, and 26 March). Another interesting feature in Animation 1 is the transport of two elevated plumes coming from Africa, a first one on 23-25 March and a second one at higher altitude on 2526 March, which recirculate over the northern Indian Ocean.

[16] Visualization of Animation 2 shows the movement of a sea-salt plume over the ocean and its episodic transport over the Indian continent. The plume of sea salt is seen all along the coast from 20 March to 22 March and then shifts to somewhat higher latitude for the rest of March (approximately from $x=0$ to 70 ). It is worth noting a plume of sea salt on 24 March entering deep inside the continent and then being lofted to higher altitudes. Lofting occurs every day between 24 and 26 March and reaches its maximum intensity around 1300 or 1500 UT.

[17] A further detailed visualization of transport of these species during periods of land and sea breeze activity is made with the help of 2D animations (see Figure 1) for the same period of time (Animations 3 and 4). These animations represent the vertical distribution of OM and dry seasalt concentrations in the transverse plane.

[18] Animation 3 confirms the timing of the features discussed above. The sea breeze affects the concentration at the surface most at 1300-1700 UT while the lofting occurs later at 2100 UT. It is also clear that the lofting occurs quite inland (points $x=45$ to 60 ) and rarely along the coast $(x=30)$. Marine air masses with low concentrations of OM appears move inland (till $x=38$ points) to a maximum distance of around $64 \mathrm{~km}$ from the coast at around $1500 \mathrm{UT}$. The plume then travels off the coast (0100 to $0700 \mathrm{UT}$ ) and hence represents the effect of land and air masses on concentration of $\mathrm{OM}$.

[19] Visualization of animation on the same plane for sea salt (Animation 4) for the same period shows a plume of sea salt during the first 2 days (20-22 March) followed by a calm period with low sea-salt concentrations. The sea-salt plume moves inland (till $x=55$ points) to a maximum distance of around $200 \mathrm{~km}$ on 20 and 21 March from 1500 until 2300 UT, which seems to last longer than for OM. We see lofting of sea salt at $x$ values of 35 to 45 points on 20 March and 30 to 45 points on 21 March. Lofting occurs closer to the coast at 1300-1700 UT, which is a bit earlier than for OM. Measurement studies [e.g., Momin et al., 1999] have reported the presence of sea salt in atmospheric aerosol at an urban location about $100 \mathrm{~km}$ inland from the west coast of India during the winter monsoon period giving evidence that synoptic flow can affect the aerosol composition deep inland to the coast. A further analysis of the effects of sea breeze on the vertical distribution and lofting of aerosols is performed by looking at their vertical profiles along the transverse and coastal planes (shown in Figure 1). The distributions are examined at 1100 and 2300 UT, which are the times of maximum contrast estimated in vertical distributions. Figure 7 represents the vertical profile of OM and sea salt in the transverse plane as an average for the period from 21 to 25 March at 1100 and 2300 UT. The isocontours for $\mathrm{OM}$ concentrations above land are slanted toward the continent at 1100 UT from $x=40$ to 60 (Figure 7a) but are vertical at 2300 UT (Figure 7b). This shows the effect of sea breeze on concentrations at 1100 UT and the presence of a stable vertically mixed layer of concentrations $(x=40$ to 60$)$ at 2300 UT. The plume of OM peaks up at 2300 UT ( $x=40$ to 60 ) and the export of $\mathrm{OM}$ to the ocean is also larger at that time while at 1100 UT the plume over the ocean exhibits a maximum at $x=25$ and is decoupled from that inland. Consistently, the sea-salt plume extends higher up at $2300 \mathrm{UT}$ as compared to 1100 UT (between $x=30$ and 45 points).

[20] Figure 8 presents the OM concentrations along the coastal plane. The formation of a plume decoupled from the surface is evident at 2300 UT (Figure $8 b$ ) as compared to that at 1100 UT (Figure 8a) between $x$ equal to 30 to 80 along the west coast. This corresponds to the region of maximum vertical mass flux of air according to Figure 3. A similar analysis made on planes parallel to the coastal plane (within longitudes 66 to $75^{\circ} \mathrm{E}$ and north to $5^{\circ} \mathrm{N}$ ) shows the lofted plume to be a permanent feature within $x=20$ to 70 points (i.e., between 10 and $18^{\circ} \mathrm{N}$ ) and an episodic feature south to $10^{\circ} \mathrm{N}$. This corroborates the $\mathrm{C}-130$ observations of high concentration of sulfate and aerosol species around $10^{\circ} \mathrm{N}$ [Gabriel et al., 2002] (see Table 1).

\section{Local-Scale and Mesoscale Effects of the Sea Breeze Circulation on Long-Range Transport}

[21] These studies are carried out at the coastal station of Goa $\left(15.45^{\circ} \mathrm{N}, 73.08^{\circ} \mathrm{E}\right)$ to evaluate the local effects of sea 

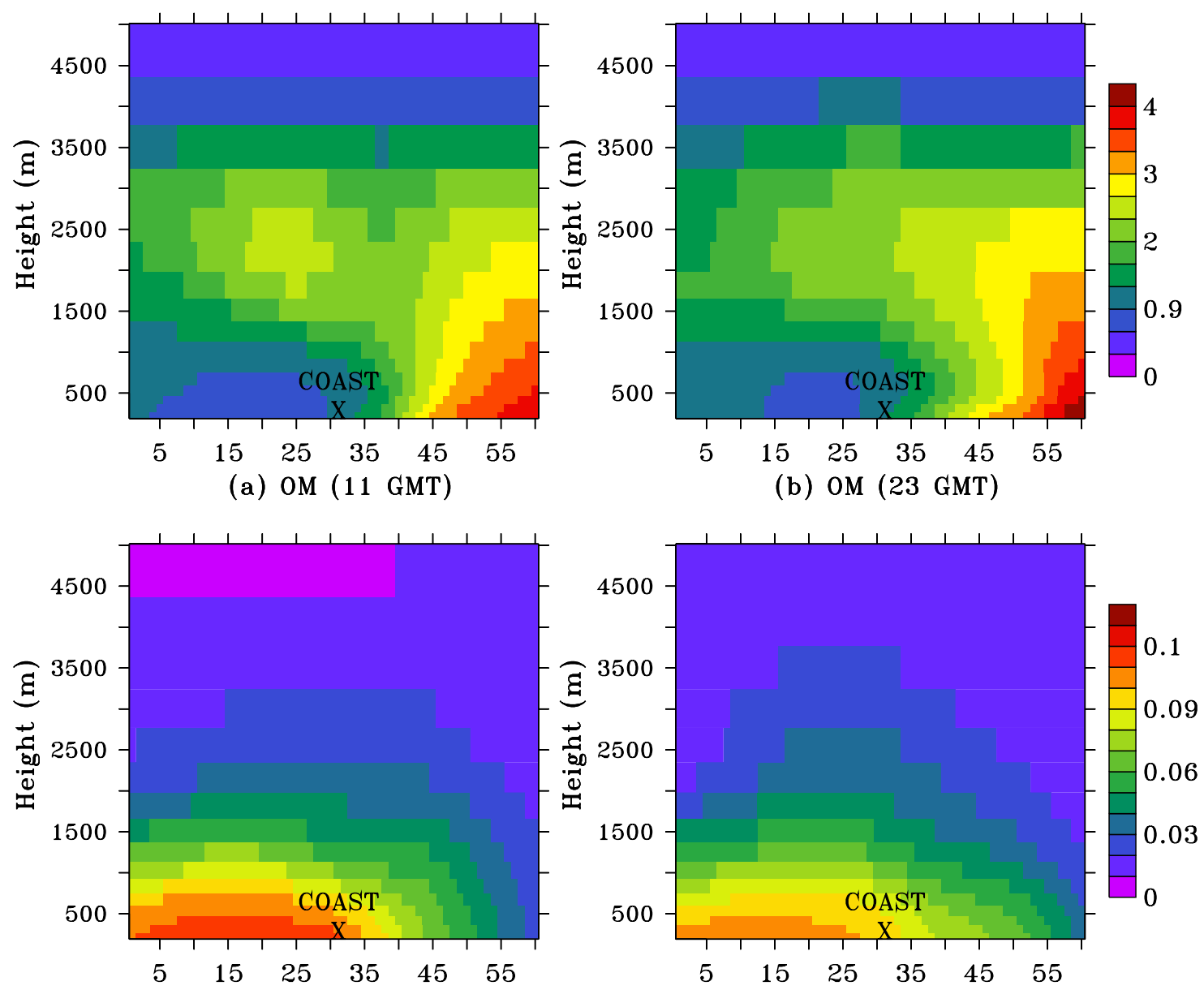

(c) Seasalt (11 GMT)

(d) Seasalt (23 GMT)

Figure 7. Vertical distribution of the average aerosol concentrations $\left(\mu \mathrm{g} \mathrm{m}^{-3}\right)$ along the transverse plane for OM at (a) 1100 UT and (b) 2300 UT and for sea salt at (c) 1100 UT and (d) 2300 UT for the period 21-25 March 1999.

breeze circulation. This study is further extended to understand the presence of lofted aerosol layers at Hulule $\left(4.4^{\circ} \mathrm{N}\right.$, $73.5^{\circ} \mathrm{E} ; 700 \mathrm{~km}$ downwind to Indian subcontinent) and the impact of sea breeze on the long-range transport.

[22] Figure 9 shows the temporal evolution of the aerosol extinction coefficient at Goa during 1-15 March 1999 with estimates from the LMD-ZT GCM and from the lidar measurements [Chazette, 2003]. Figure 9a reveals the presence of diurnal variations in the extinction coefficient close to the surface $(0-0.7 \mathrm{~km})$. The maximum extinction coefficient occurs around 1200 UT at the surface and propagates upward. At $1 \mathrm{~km}$ altitude, the maximum occurs around 0000 UT. The GCM also captures some diurnal variations at higher altitude $(1.5-3 \mathrm{~km})$ but it is masked by day-to-day variability. For the period 5 to 8 March, the average extinction coefficient at $1.5-3 \mathrm{~km}$ peaks at 1800 UT. The temporal evolution of the aerosol extinction coefficient from the lidar measurements is shown in Figure 9b. The surface aerosol layer is well mixed over the altitude range of 0.11 to $0.7 \mathrm{~km}$ and does not show a clear diurnal variability. However, the layer between 0.7 and $4 \mathrm{~km}$ shows larger extinction coefficient during nighttime than daytime [Chazette, 2003]. There are both areas of agreement and disagreement between the modeled and

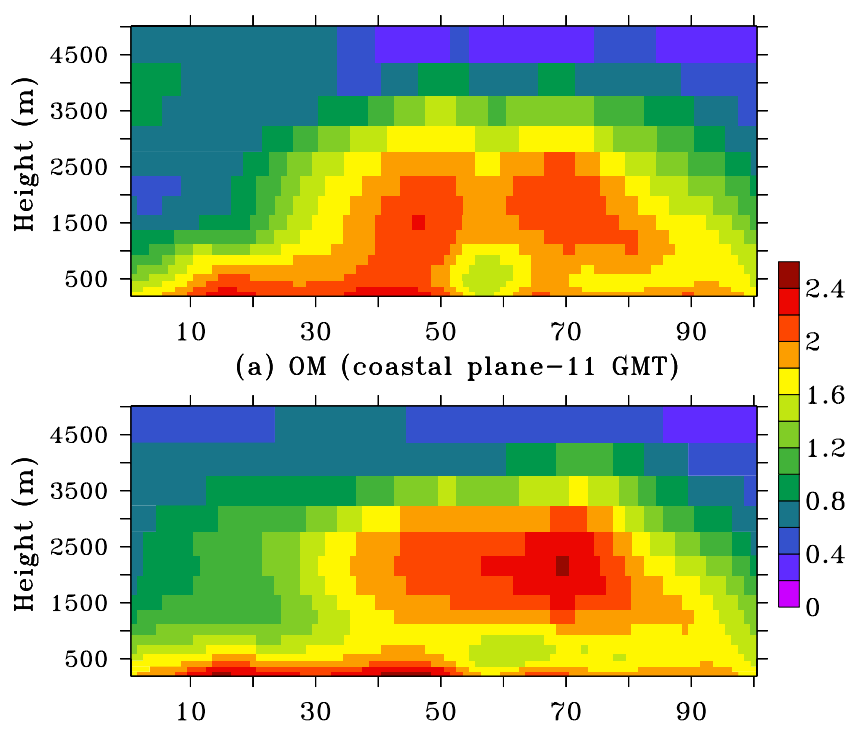

(b) OM (coastal plane-23 GMT)

Figure 8. Vertical distribution of average aerosol concentrations $\left(\mu \mathrm{g} \mathrm{m}^{-3}\right)$ along the coastal plane for OM at (a) 1100 and (b) 2300 UT for the period from 21 to 25 March 1999. 


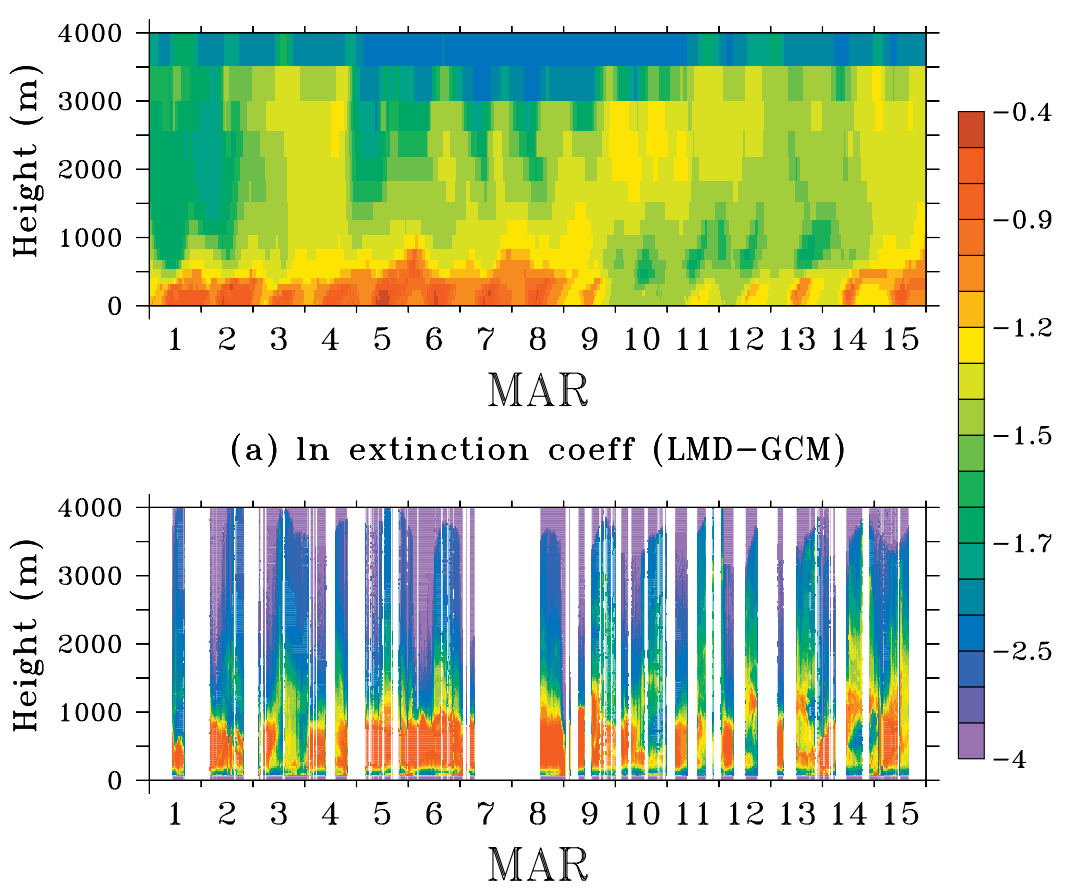

(b) ln extinction coeff (Lidar measurements)

Figure 9. Temporal evolution at Goa of the aerosol vertical profile (log to the base of 10 of the aerosol extinction coefficient in units of $\mathrm{km}^{-1}$ ) at $532 \mathrm{~nm}$ from (a) the GCM simulation and (b) the lidar measurements of Chazette [2003] between 1 and 15 March 1999. The $x$ axis corresponds to days in March in universal time. The lidar measurements should not be trusted in the first $200 \mathrm{~m}$ because of incomplete overlap between the lidar beam and the receiver field of view.

observed aerosol profiles at Goa. The model simulates a diurnal cycle at the surface which is not really seen in the lidar profiles, but which is in agreement with surface-based measurements of the scattering coefficient, with larger values during nighttime (Figure 8 from Chazette [2003]). The variability in the upper layer $(1.5-3 \mathrm{~km})$ is less marked in the model than in the observations, but is in phase with observations for the period 6-8 March. The model underestimates the aerosol extinction coefficient in the surface layer by a factor of $2-4$, but spreads the layer too much over the vertical, which tends to largely over estimate it in the 1 to $3.5 \mathrm{~km}$ altitude range. This provides an explanation as to why the model under predicts surface concentrations over the region as mentioned by Reddy et al. [2004].

[23] Figure 10 shows the vertical profile of the aerosol extinction coefficient as derived from the six-wavelength lidar at Hulule [Althausen et al., 2000; Franke et al., 2003] and as estimated by the LMD-ZT GCM. Here we evaluate the lofted features of plume observed at Hulule and that from model estimates. Measurements are available for two periods (6-10 March) and (17-24 March) with profiles restricted to altitude larger than $1 \mathrm{~km}$. The error of the extinction coefficients is around $20 \%$. The minimum height is given by the incomplete overlap between laser beam and the field of view of the receiver telescope. For a detailed explanation we refer to Franke et al. [2003]. Below 1 km height we estimated the particle extinction profile. For that we used the profiles of the particle backscatter coefficients, which reach almost down to the surface. In addition, one has to assume a particle backscatter-to-extinction (lidar) ratio. The lidar ratio was chosen on the basis of values measured around $1 \mathrm{~km}$ height, and then used to convert the profiles of the backscatter coefficients into profiles of the extinction coefficients. In the estimate of the lidar ratio we also took account of optical depth, measured with Sun photometer at Hulule close to sunset [Franke et al., 2003]. In combination with Raman lidar observations carried out after sunset one may roughly estimate optical depth below $1 \mathrm{~km}$ height, and thus evaluate the uncertainty of the chosen lidar ratio. The uncertainty of the lidar ratio, and thus of the extinction coefficients increases with decreasing height. We assume that below $500 \mathrm{~m}$ height the estimated profiles of the extinction coefficients may reach $50 \%$. In the lidar measurements, elevated extinction from aerosol plumes was measured between 2 and $3 \mathrm{~km}$ height, possibly on 10 and 21 March and that between 0.5 and $1.5 \mathrm{~km}$ height during 6 March to 9 March (Figures 10a and 10b). Model vertical profiles (Figures 10c and 10d), which have been averaged over the times of measurement, appear to capture the lofted aerosol features at lower heights during the corresponding periods of lidar measurement. While the model does not capture the lofted aerosol features at higher heights on corresponding days of their measurement, it does estimate lofted aerosol features between 2 and $3 \mathrm{~km}$ on 11 and 23 March. We also show the time evolution of the vertical profile of the extinction coefficient at Hulule for the full period of simulation in Figure 11. Figure 11 shows the presence of lofted layers on 11 March and 23 March between 2 and $2.5 \mathrm{~km}$ height. It also shows episodes of lofted layers on 9 March, and 24 at about 1-2 km height 


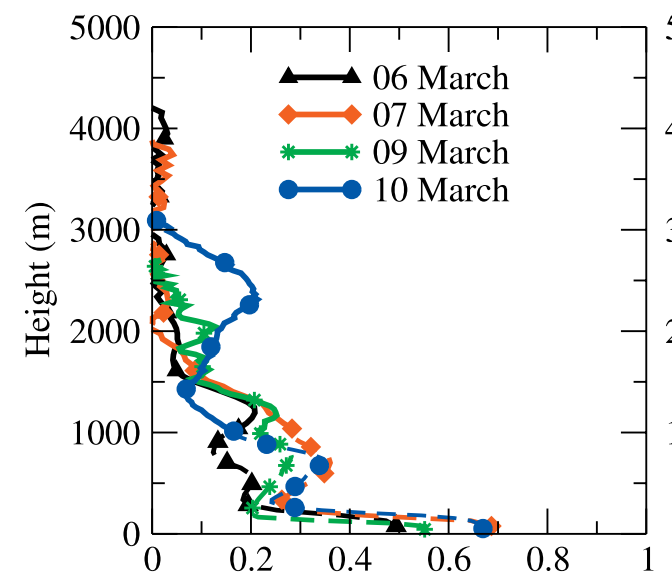

(a) Ext. coeff. $\left(\mathrm{km}^{-1}\right)$ - Lidar

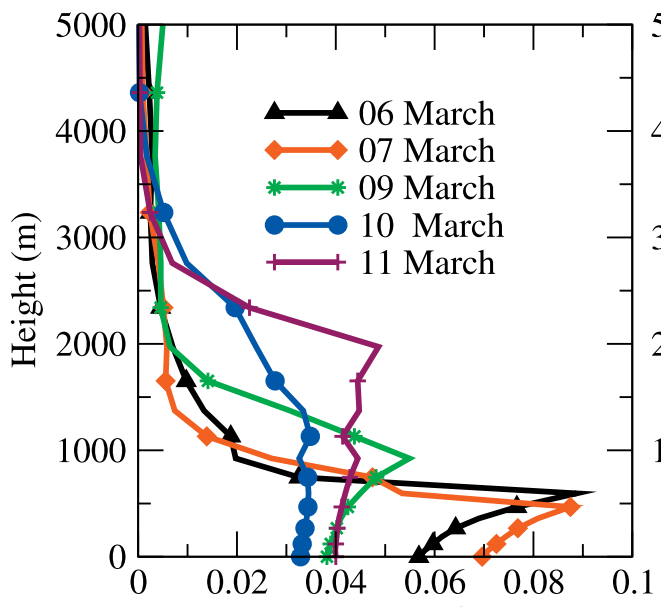

(c) Ext. coeff. $\left(\mathrm{km}^{-1}\right)-\mathrm{GCM}$

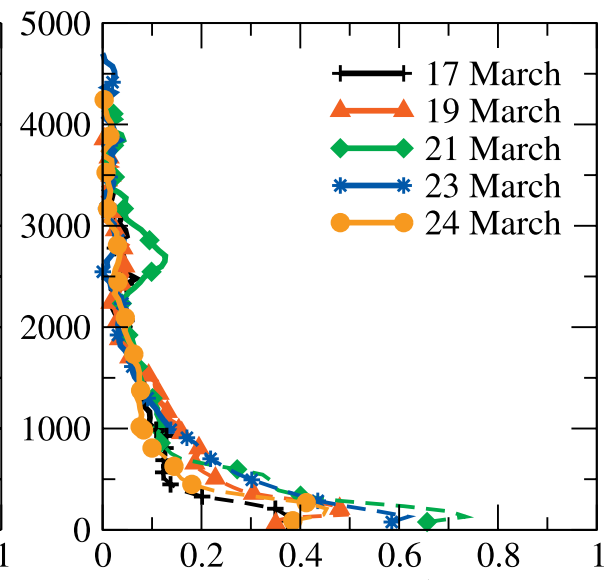

(b) Ext. coeff. $\left(\mathrm{km}^{-1}\right)$ - Lidar

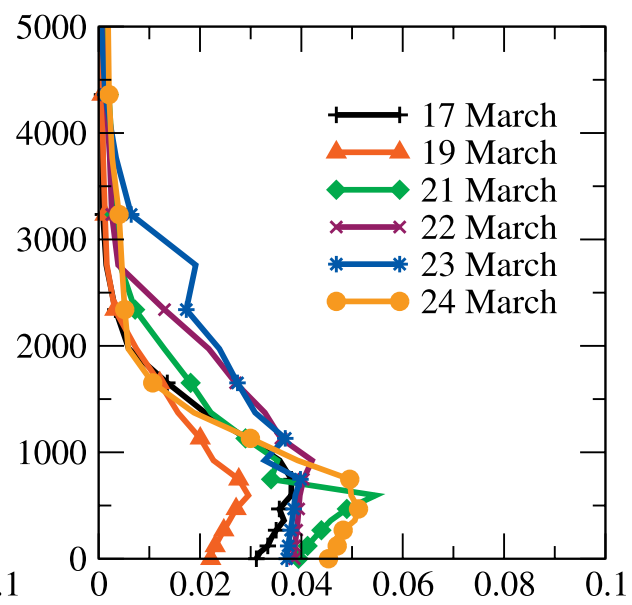

(d) Ext. coeff. $\left(\mathrm{km}^{-1}\right)$ - GCM

Figure 10. Vertical profile of the aerosol extinction coefficient $\left(\mathrm{km}-{ }^{1}\right)$ at Hulule at $532 \mathrm{~nm}$ from (a and b) lidar (shown are measured extinction profiles (solid lines) and estimated extinction profiles below $1 \mathrm{~km}$ height (dash-dotted lines); errors of the lidar profiles are given in the text) and (c and d) GCM simulation for the period from 6 to 11 March 1999 (Figure 10c) and (d) 17 to 24 March 1999 (Figure 10d).

and on 26 February, and 5, 6, 20, and 21 March at about $0.5-1 \mathrm{~km}$. It appears that the model shows up the lofted features between 0.5 to $1 \mathrm{~km}$ on 6 and 9 March corresponding to period of lidar observations. However, the model is not able to capture the episodic periods of lofted layers for 10 and 21 March in the lidar observations; lofted features are simulated in the model on 11 March and 23 March possibly corresponding to 10 and 21 March in lidar observations. The delayed appearance of lofted plume in model at higher layers may be due to inaccuracies in the wind fields. The model underestimates the extinction coefficient by a factor of 5 to 6 as compared to measurements. We believe that this is due to both a spurious overestimation of the precipitation rate in the model over the Arabian Sea [Reddy et al., 2004] and inaccuracies in the wind fields of ECMWF which are used to nudge the model [Bonazzola et al., 2001].

\section{Conclusions}

[24] Analysis of wind field data from ECMWF showed the presence of intense sea breeze activity at 1200 UT

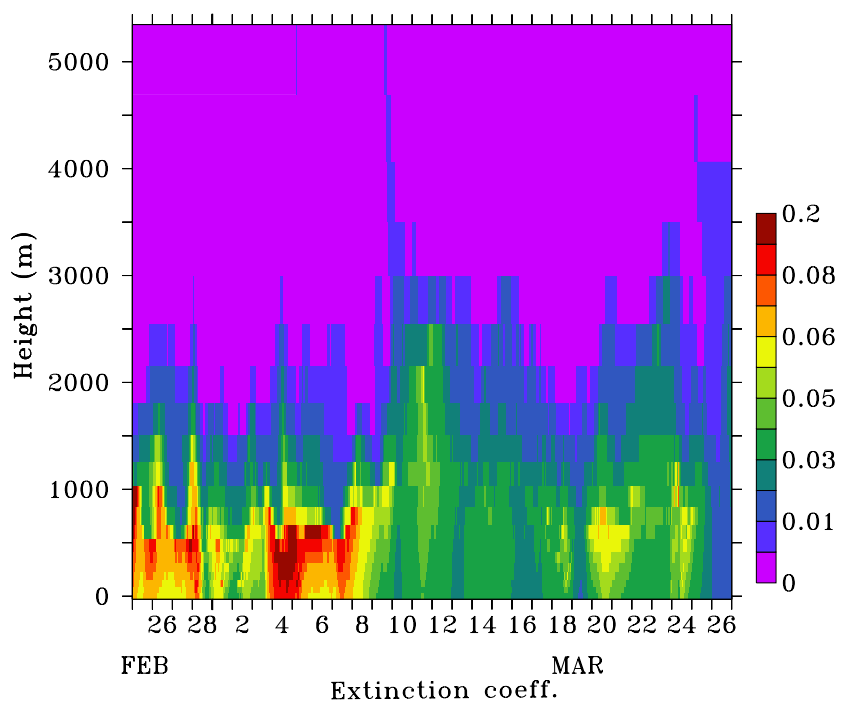

Figure 11. Simulated temporal evolution between 25 February and 26 March 1999 of the vertical profile of the aerosol extinction coefficient $\left(\mathrm{km}^{-1}\right)$ at $532 \mathrm{~nm}$ at Hulule. 
(1730 LT) along the west coast of India. The average intensity of sea breeze is $\left(1.4 \mathrm{~m} \mathrm{~s}^{-1}\right)$ in February. Significantly larger values of $3.4 \mathrm{~m} \mathrm{~s}^{-1}$ were found for March. Upward mass flux of air was observed everywhere along the west coast of India (from 8 to $20^{\circ} \mathrm{N}$ ) because of convergence between the sea breeze and the northeast monsoon winds with higher intensity of upward motion observed in March $\left(0.24 \mathrm{~Pa} \mathrm{~s}^{-1}\right)$ as compared to February $\left(0.12 \mathrm{~Pa} \mathrm{~s}^{-1}\right)$ and hence greater potential for aerosol lofting. Lofting of air above $800 \mathrm{mb}(2 \mathrm{~km}$ asl $)$ along the coast leads to entrainment of aerosols into the free troposphere causing their large-scale advection. To study the effects of sea breeze on aerosols, a general circulation model (GCM) was nudged with ECMWF wind fields to ensure that the model captures the patterns of sea breeze which are evident in the ECMWF data. The model simulates the concentrations of different aerosol species as well as the aerosol extinction coefficient, which were analyzed to study effects of sea breeze on the vertical distribution and lofting of aerosols. The model results are compared to observations at the coastal station of Goa and at Hulule, $700 \mathrm{~km}$ downwind to Indian subcontinent, in order to understand the local-scale and mesoscale effects of sea breeze circulation and long-range transport. A well-developed lofted layer of aerosols as high as $3 \mathrm{~km}$ is estimated for the period averaged from 21 March to 25 March along the west coast of India. This period corresponds to episodes of pollution layers observed over the Indian Ocean region. The model simulates diurnal variations due to local sea breeze effects in the aerosol extinction coefficient at Goa but fails to reproduce the marked diurnal variability of upper layers between 1 to $3 \mathrm{~km}$ as seen in lidar observations. The model simulates diurnal cycle at surface $(0-0.7 \mathrm{~km})$ which is not apparent in lidar measurements. The model simulates long-range transport, $700 \mathrm{~km}$ downwind the west coast of India. However, there was a 1-2 day delay in the model transport of lofted aerosols at higher layers to Hulule, $700 \mathrm{~km}$ downwind of India when compared to lidar observations. We believe that a thinner vertical resolution and better analyzed wind fields are needed to improve the simulations of long-range transport of aerosol layers over this region.

[25] Acknowledgments. Computing resources at IIT Bombay were supported through a grant from the Indian Ministry for Human Resource Development. We are thankful to the European Centre for Medium-Range Weather Forecasts (ECMWF) and the Institut Pierre-Simon Laplace (IPSL) for providing us with analysis of wind fields. A significant part of this work was accomplished through computing time provided by the Institut du Développement et des Ressources en Informatique Scientifique (IDRIS) of the CNRS under projects 031167 and 041167 . S. Verma acknowledges support from START and the French Embassy in India for her two visits to LOA (France). This study is part of a collaborative project also supported by the Indo-French Centre for the Promotion of Advanced Research (IFCPAR)

\section{References}

Althausen, D., D. Müller, A. Ansmann, U. Wandinger, H. Hube, E. Clauder, and S. Zörner (2000), Scanning 6-wavelength 11-channel aerosol lidar, J. Atmos. Oceanic Technol., 17, 1469-1482.

Ansmann, A., D. Althausen, U. Wandinger, K. Franke, D. Müller, F. Wagner, and J. Heintzenberg (2000), Vertical profiling of the Indian aerosol plume with six-wavelength lidar during INDOEX: A first case study, Geophys. Res. Lett., 27(7), 963-966.

Ball, W., R. Dickerson, B. Doddridge, J. Stehr, T. Miller, D. Savoie, and T. Carsey (2003), Bulk and size aggregated aerosol composition observed during INDOEX 1999: Overview of meteorology and continen- tal impacts, J. Geophys. Res., 108(D10), 8001, doi:10.1029/ 2002JD002467.

Bonazzola, M., L. Picon, H. Laurent, F. Hourdin, G. Sèze, H. Pawlowska, and R. Sadourny (2001), Retrieval of large-scale wind divergences from infrared Meteosat-5 brightness temperatures over the Indian Ocean, J. Geophys. Res., 106(D22), 28,113-28,128.

Boucher, O., M. Pham, and C. Venkataraman (2002), Simulation of the atmospheric sulfur cycle in the Laboratoire de Météorologie Dynamique general circulation model: Model description, model evaluation and global and European budgets, Note Sci. 23, Inst. Pierre-Simon Laplace, Paris.

Chazette, P. (2003), The monsoon aerosol extinction properties at Goa during INDOEX as measured with lidar, J. Geophys. Res., 108(D10), 4187, doi:10.1029/2002JD002074.

Collins, W., P. Rasch, B. Eaton, B. Khattatov, J. Lamarque, and C. Zender (2001), Simulating aerosols using a chemical transport model with assimilation of satellite aerosol retrievals: Methodology for INDOEX, J. Geophys. Res., 106(D7), 7313-7336.

Franke, K., A. Ansmann, D. Müller, D. Althausen, C. Venkataraman, M. S. Reddy, and R. Scheele (2003), Optical properties of the Indo-Asian haze layer over the tropical Indian Ocean, J. Geophys. Res., 108(D2), 4059, doi:10.1029/2002JD002473.

Gabriel, R., O. Mayol-Bracero, and M. Andreae (2002), Chemical characterisation of submicron aerosol particles collected over the Indian Ocean, J. Geophys. Res., 107(D19), 8005, doi:10.1029/2000JD000034.

Hourdin, F., and A. Armangaud (1997), The use of finite-volume methods for atmospheric advection of trace species. Part 1: Test of various formulations in a general circulation model, Mon. Weather Rev., 127, 822837.

Krishnamoorthy, K., A. Saha, B. Prasad, K. Niranjan, D. Jhurry, and P. Pillai (2001), Aerosol optical depths over peninsular India and adjoining oceans during the INDOEX compaigns: Spatial, temporal, and spectral characteristics., J. Geophys. Res., 106(D22), 28,539-28,554.

Lelieveld, J., et al. (2001), The Indian Ocean Experiment: Widespread air pollution from south and Southeast Asia, Science, 291, 10311036.

Leon, J.-F., et al. (2001), Large scale advection of continental aerosols during INDOEX, J. Geophys. Res., 106(D22), 28,427-28,440.

Li, Z.-X. (1999), Ensemble atmospheric GCM simulation of climate interannual variability from 1979 to 1994 , J. Clim., 12, 986-1001.

Mayol-Bracero, O., R. Gabriel, M. Andreae, T. Kirchstetter, T. Novakov, J. Ogren, P. Sheridan, and D. Streets (2002), Carbonaceous aerosols over the Indian Ocean during INDOEX: Chemical characterisation, optical properties and probable sources, J. Geophys. Res., 107(D19), 8030, doi:10.1029/2000JD000039.

Miller, S., B. Keim, R. Talbot, and H. Mao (2003), Sea breeze: Structure, forecasting, and impacts, Rev. Geophys., 41(3), 1011, doi:10.1029/ 2003RG000124.

Minvielle, F., et al. (2004a), Modeling of the transport of aerosols during INDOEX 1999 and comparison with experimental data. Part 1: Carbonaceous aerosol distribution, Atmos. Environ., 38(12), $1811-1822$

Minvielle, F., et al. (2004b), Modeling transport of aerosols during INDOEX 1999 and comparison with experimental data. Part 2: Continental aerosol and their optical depth, Atmos. Environ., 38(12), $1823-1837$.

Momin, G., P. Rao, A. P. D. K.Safai, M. Naik, and A. Pillai (1999), Atmospheric aerosol characteristic studies at Pune and Thiruvananthapuram during INDOEX programme: 1998, Current Sci., 76(7), 985-989.

Müller, D., K. Franke, F. Wagner, D. Althausen, A. Ansmann, and J. Heintzenberg (2001a), Vertical profiling of optical and physical particle properties over the tropical Indian Ocean with six-wavelength lidar: 1. Seasonal cycle, J. Geophys. Res., 106(D22), 28,567-28,575.

Müller, D., K. Franke, F. Wagner, D. Althausen, A. Ansmann, and J. Heintzenberg (2001b), Vertical profiling of optical and physical particle properties over the tropical Indian Ocean with six-wavelength lidar: 2. Case studies, J. Geophys. Res., 106(D22), 28,577-28,595.

Pelon, J., C. Flamant, P. Chazette, J.-F. Léon, D. Tanré, M. Sicard, and S. Satheesh (2002), Characterisation of aerosol spatial distribution and optical properties over the Indian Ocean from airborne lidar and radiometry during INDOEX 99, J. Geophys. Res., 107(D19), 8029, doi:10.1029/2001JD000402.

Raman, S., D. Niyogi, M. Simpson, and J. Pelon (2002), Dynamics of elevated plume over the Arabian Sea and the northern Indian Ocean during northeasterly monsoons and during the Indian Ocean Experiment (INDOEX), Geophys. Res. Lett., 29(16), 1817, doi:10.1029/ $2001 \mathrm{GL} 014193$.

Ramanathan, V., et al. (2001), An integrated analysis of the climate forcing and effects of the great Indo-Asian haze, J. Geophys. Res., 106(D22), $28,371-28,398$. 
Rasch, P., W. Collins, and B. Eaton (2001), Understanding the Indian Ocean Experiment (INDOEX) aerosol distributions with an aerosol assimilation, J. Geophys. Res., 106(D7), 7337-7355.

Reddy, M. S., and O. Boucher (2004), Global carbonaceous aerosol transport and assessment of radiative effects in the LMDZ GCM, J. Geophys. Res., 109, D14202, doi:10.1029/2003JD004048.

Reddy, M. S., and C. Venkataraman (2002a), Inventory of aerosol and sulfur dioxide emissions from India: I. Fossil fuels combustion, Atmos. Environ., 36, 677-697.

Reddy, M. S., and C. Venkataraman (2002b), Inventory of aerosol and sulfur dioxide emissions from India: II. Biomass combustion, Atmos. Environ., 36, 699-712.

Reddy, M. S., O. Boucher, C. Venkataraman, S. Verma, J.-F. Leon, and M. Pham (2004), GCM estimates of aerosol transport and radiative forcing during INDOEX, J. Geophys. Res., 109, D16205, doi:10.1029/ 2004JD004557.

Reddy, M. S., O. Boucher, N. Bellouin, M. Schulz, Y. Balkanski, and M. Pham (2005), Estimates of global multicomponent aerosol optical depth and direct radiative perturbation in the Laboratoire de Météorologie Dynamique general circulation model, J. Geophys. Res., 110, D10S16, doi:10.1029/2004JD004757.

Reiner, T., D. Sprung, C. Jost, R. Gabriel, O. Mayol-Bracero, M. Andreae, T. Campos, and R. Shetter (2001), Chemical characterisation of pollution layers over the tropical Indian Ocean: Signatures of biomass burning emissions, J. Geophys. Res., 106(D22), 28,497-28,510.

Simpson, M., and S. Raman (2005), Development and propagation of a pollution gradient in the marine boundary layer during INDOEX (1999), J. Earth Syst. Sci., 114(1), 3-16.

Streets, D., et al. (2003), An inventory of gaseous and primary aerosol emissions in Asia, J. Geophys. Res., 108(D21), 8809, doi:10.1029/ 2002JD003093.
Tiedtke, M. (1989), A comprehensive mass flux scheme for cumulus parameterization in large-scale models, Q. J. R. Meteorol. Soc., 107, 17791800 .

van Leer, B. (1977), Towards the ultimate conservative difference scheme: IV. A new approach to numerical convection, J. Comput. Phys., 23, 276299

Wagner, F., D. Müller, and A. Ansmann (2001), Comparison of the radiative impact of aerosols derived from vertically resolved (lidar) and vertically integrated (sunphotometer) measurements: Example of an Indian aerosol plume, J. Geophys. Res., 106(D19), 22,86122,870 .

O. Boucher, Hadley Centre, Met Office, Fitzroy Road, Exeter EX1 3PB, UK. (olivier.boucher@metoffice.gov.uk)

P. Chazette, Laboratoire des Sciences du Climat et de 1'Environnement, CEA-CNRS, Orme des Merisiers, F-91191 Gif sur Yvette Cedex, France. (pch@1sce.saclay.cea.fr)

B. Crouzille, Laboratoire d'Optique Atmosphérique, CNRS-Université des Sciences et Technologies de Lille, F-59655 Villeneuve d'Ascq Cedex, France. (crouzill@loa.univ-lille1.fr)

D. Müller, Leibniz Institute for Tropospheric Research, Permoserstrasse 15, D-04318 Leipzig, Germany. (detlef@tropos.de)

M. S. Reddy, NOAA Geophysical Fluid Dynamics Laboratory, Princeton Forrestal Campus, 201 Forrestal Road, Princeton, NJ 08540, USA. (shekar.reddy@noaa.gov)

C. Venkataraman and S. Verma, Department of Chemical Engineering, Indian Institute of Technology, Bombay, Mumbai-400 076, India (chandra@iitb.ac.in; shubha@iitb.ac.in) 